\title{
The Role of Tourism Activists in Supporting the Tourism with Environmental Based Through Cultural Performances "Hajat Leuweung" in Selasari Village, Parigi Subdistric, Pangandaran District
}

\author{
Iraian Bakti ${ }^{1}$, Suwandi Sumartias ${ }^{2}$, Trie Damayanti ${ }^{3}$, Aat Ruchiat Nugraha ${ }^{4}$ \\ \{iriana.bakti@unpad.ac.id ${ }^{1}$, suwandi.sumartias@unpad.ac.id ${ }^{2}$, trie.damayanti@unpad.ac.id ${ }^{3}$ \\ ruchiat@unpad.ac.id $\left.{ }^{4}\right\}$ \\ ${ }^{1,2,3,4}$ Faculty of Communication Science, Padjadjaran University, Jl. Raya Bandung-Sumedang \\ Km.21, Jatinangor 45363
}

\begin{abstract}
Tourism-based on local wisdom and sustainable environment is a priority for development because it has a value of social, economic, and education that can build awareness, and the convenience of tourists to visiting the region. To develop such tourism objects, tourism and environmental activists in Selasari Village, Parigi SubDistrict, Pangandaran District held a cultural performance "Hajat Leuweung" and structuring the environment of the tourist objects with the aim is to building sights attitude and behavior of the public towards sustainable environmental preservation. This research aims to find out the reason, meaning, the actuator and the role of the environment in such activities. The research method used is descriptive to describe all activities associated with the event. The selected informants were the selected active environmental activists that developing and promoting local wisdom-based tourist attraction that is specified in purposive. The results showed that the reason for tourism and cultural activists organized a cultural performance and environmental attractions Setup is to continued the tradition of the ancestors, preserving the beauty, and provide comfort. The meaning of cultural performance and environment setup is equivalent to mutual attraction, gratitude, and thanks to God, and the spirit high. While the role of tourism and culture in the actuator performances and structuring the environment attractions is organizing the environment, environmental education, and to scatter widely the environmental information.
\end{abstract}

Keywords: hajat leuweung, environment, social wisdom, mutual cooperation, communication.

\section{Introduction}

Pangandaran is one of the regencies in West Java that has the potential to be a natural tourist destination environmentally. The potential of this nature is the attraction because in it includes a factor of nature conservation, empowerment social-cultural local community economy as well as the aspects of learning and education. Natural attractions such as the Grand Canyon, Goa Sutra Reregan, Santirah Rafting, Goa Lanang. into another alternative for tourists to pay a visit to Pangandaran Beach tourism, and in addition to the nature reserve. The addition of these tourism objects can increase regional income, reduce labor, open business 
opportunities for local communities, and so on. The opening of attractions besides the beach is inseparable from the efforts of community members who care about the potential of their region in the field of tourism. They are tourism and cultural activists who work hard to open, maintain, and promote non-coastal tourism objects, which is in its execution begins with communication in the form of dialogue to equal the perception and collaboration with stakeholders. This is emphasized by the research from Vaulvoulis (2017) [1], [2], [3].

One of the tourism objects promoted by tourism and cultural activists in Pangandaran is nature tourism in the form of a cave trail (Reregan, Silk, and Lanang), and the Santirah Rafting in Selasari Village, Parigi Sub-District, Pangandaran District. They promote these tourism objects with a cultural performance "Hajat Leuweung".

"Hajat Leuweung" is not simply a cultural event to promote tourism in the region, but it contained neighborhood values can be used as lessons for maintaining a sustainable environment. This is confirmed by the research of [4], [5], [6].

In addition, the treatment of its own sights are always paying attention to the environment, such as the handling of trash, tree planting, care of the environment of the surrounding forest encroachment, and spread the information about waste problems that pollute the river through the media. This is emphasized from the research conducted by [7], [8], and [9].

\section{Result and Discussion}

Tourism and cultural activists in Pangandaran District are individuals who come from various elements, such as teachers, village officials, sub-district employees, members of the youth organization, and so on. They are moved to promote tourism objects through cultural performances "hajat leuweung", and at the same time maintain, maintain, and preserve the natural environment that is in the location of tourist objects located in their respective regions. The activities carried out by them are an implementation of their role as tourism and cultural activists. The reason for conducting cultural events "hajat leuweung", and environmental arrangement by tourism and cultural activists is to continue the ancestral habits to preserve the environment as a source of life, maintain the environment for the beauty of tourist objects from damage, maintain the environment for the convenience of visitors.

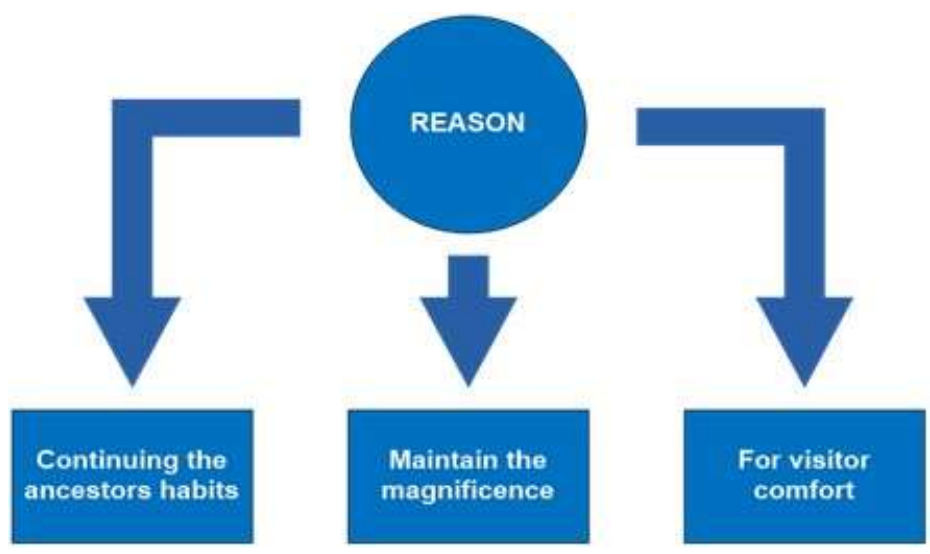

Fig. 1. The Reason for Making Environmental Arrangements 
Tourism and cultural activists state that the reason for performing cultural performances "hajat leuweung", and the arrangement of the environment of the tourist objects is based on the experiences of the previous people whom he "learned" so that he became a provision of knowledge and provision of life for himself. The life experience of environmental activists is the seeing, feeling, thinking, and acting in accordance with the situations and conditions that occur in the surrounding environment where he lives and interacts, so that from the experience environmental activists recognize the surrounding social facts, and at the same time determine the limits for doing something as a realization of their consciousness.

The experiences gained during the interaction are the reasons for him to perform "hajat leuweung" performances, and the arrangement of the tourist environment because of the desire to "continue the ancestral habits" in an effort to preserve the environment as a source of life. The emergence of these reasons does not come just like that, they read, and hear, even do something in their daily lives how ancestors treat the environment.

Tourism and cultural activists assume that what the ancestors have done is an effective way to carry out the ritual of hajat leuweung and the arrangement of the environment. Therefore they preserve it with the assumption that the habit is very useful in building a sustainable living environment. The habits of the ancestors are a source of knowledge for tourism activists in environmental management because they are humans who are close to nature, which has a high level of environmental literacy. The ancestors have the good capability to read natural phenomena, so they can produce knowledge and pass on their knowledge to the present generation. Tourism and cultural activists are individuals who become heirs to ancestral habits in environmental management, where they gain knowledge about the habits of their ancestors since they are in the family, community, and social organizations (tourism activists group), and from the media (social).

The family environment becomes the first source of knowledge about the environment that has been conducted by ancestors before. Hereditary habits by the family lead to tourism and cultural activists accustomed to treating the environment in accordance with the habits of their ancestors. Like planting and maintaining plants, not littering, cleaning the environment, and so on. The environmental maintenance habits that are obtained in the family environment become provision for themselves to do the same in the community. Interaction within the community builds awareness of tourism and cultural activists that he gets positive and negative judgments from others. With this awareness, then they must prepare themselves to explain the importance of managing a better environment, and at the same time must relearn about the environment from other community members whose level of knowledge and experience is higher than themselves. For this reason, a dialogue with all stakeholders is needed to equate perception in responding appropriately to everything that is of concern [1].

The medium to pass on more comprehensive environmental values is obtained by tourism and cultural activists in social organizations. In general, they are gathered in the tourism activists group (Kompepar). This group has a commitment to building tourism activities based on local wisdom values by taking into account its potential and supporting factors, namely a sustainable environment. Therefore the best way to preserve tourist destinations from social, cultural and environmental degradation must apply the principles of sustainability to reduce profligacy [4].

As an association, members of the compartment are bound by the same rules to achieve common goals effectively and efficiently. Tourism and cultural activists who are members of Kompepar work together to build and promote tourism objects through the performance of "hajat leuweung", and the arrangement of the environment of the tourism objects. Collaboration between them became one of its basic capital. 
The medium to inherit the environmental values used are government institutions, especially those related to tourism activities, namely the Tourism and Culture Office of Pangandaran District. Tourism and cultural activists must synergize with this institution because it is one of the policy-making institutions in the tourism sector.

There are four tourism programs implemented by this institution. First, the development of destinations, both the development of the tourism industry, the three marketing, and the four institutions and partnerships. The synergy that must be built with tourism and cultural activists is a partnership because both parties need each other. The government created a partnership program because it must involve tourism and cultural activists as stakeholders who have the knowledge, skills, and experience in opening and promoting local wisdom-based and environmental attractions so that their voices can be accommodated in the process of tourism policy making.

The management of a cultural performance "hajat leuweung", and the structuring of the tourism object is the proof that tourism and cultural activists have the knowledge, skills, and experience in the field. Therefore, they become one of the important components in the success of tourism programs based on local wisdom and the environment in Pangandaran District.

The reason for tourism and cultural activists to perform "hajat leuweung" performances and the arrangement of the tourist environment is to "maintain the beauty" of tourism objects from damage, showing that within themselves awareness has emerged about environmental aesthetic values. Maintaining the beauty of tourism objects is very important for them because it becomes a strong carrying capacity to attract tourists to visit it. Tourism and cultural activists realize that maintaining the beauty (aesthetics) of the environment is an element that greatly determines the quality of the attractions they manage. Therefore, the arrangement of cultural performances "hajat leuweung" and the locations that are used as tourism objects are made as beautiful as possible with various attributes that are full of symbolic meanings, such as the participants and visitors dressed in adat, making tumpeng, providing torches and eating and drinking utensils made of brass, etc.

Environmental aesthetics developed by tourism and cultural activists objectively in the "hajat leuweung" cultural performance and structuring their objects can be a filter against various negative influences that can damage the quality and are harmful to the preservation of nature and culture in Pangandaran. Therefore, they then sharpened the ability to appreciate art and culture (local wisdom) which is still taking place in Pangandaran by learning from the elders, so that the beauty can be felt by visitors.

The reasons for tourism and cultural activists to perform "hajat leuweung" performances, and arrangement of tourist attractions because for the convenience of visitors shows that they pay attention to environmental ethics because basically, humans are an integral part of their environment. Therefore, humans must be made comfortable when they are in their environment, including in the tourist attractions they visit. The efforts to make tourists comfortable when visiting cultural events "Hajat Leuweung", and their tourism objects are the implementation of all forms of deeds that are considered good for humans and the surrounding environment. These efforts can bring people closer to the natural surroundings. This can happen if humans can feel and understand the deepest values contained in nature [10]. This closeness shows the relationship between tourism and cultural activists and tourists that can result in a harmonious relationship between humans and humans, and humans and nature.

The convenience in public spaces (tourism objects) built by tourism and cultural activists is a product of their moral wisdom in interacting with their environment in order to achieve the environmental balance. Moral policies produced by tourism and cultural activists are 
conveyed in the cultural show "hajat leuweung" which is a legacy of local ancestors, and structuring of its tourism objects, so that its comfort is not only intended for humans, but all creatures in it, because for tourism and cultural activists, all beings have the same rights to be treated fairly. So the environmental ethics applied by them is environmental ethics which includes both.

The reasons conveyed by environmental and cultural activists for participating in building and promoting tourism objects through the cultural performance "hajat leuweung" and the arrangement of tourism objects in the Selasari Village, Parigi Sub-District, Pangandaran District, showed that they had understood the principles of environmental ethics, namely respect for nature, having the moral responsibility to nature, having cosmic solidarity, having compassion and caring for nature, not harming or damaging the environment, simplicity, and harmony with nature, and justice with nature.

The cultural performance "hajat leuweung" and the arrangement of its objects is a means for tourism and cultural activists to interact in order to build and promote local wisdom-based tourism objects and the environment. The social experience gained by environmental activists is formed, after interacting, both with fellow tourism and cultural activists, as well as with the community and other stakeholders, this is a learning process that influences its accuracy to perceive, and the results become the basis for itself to give meaning to what it does.

The meaning of "hajat leuweung" according to tourism and cultural activists involved in the performance is mutual cooperation, high enthusiasm to build the environment, gratitude, and thanks to God for the wealth that is gained in the forest.

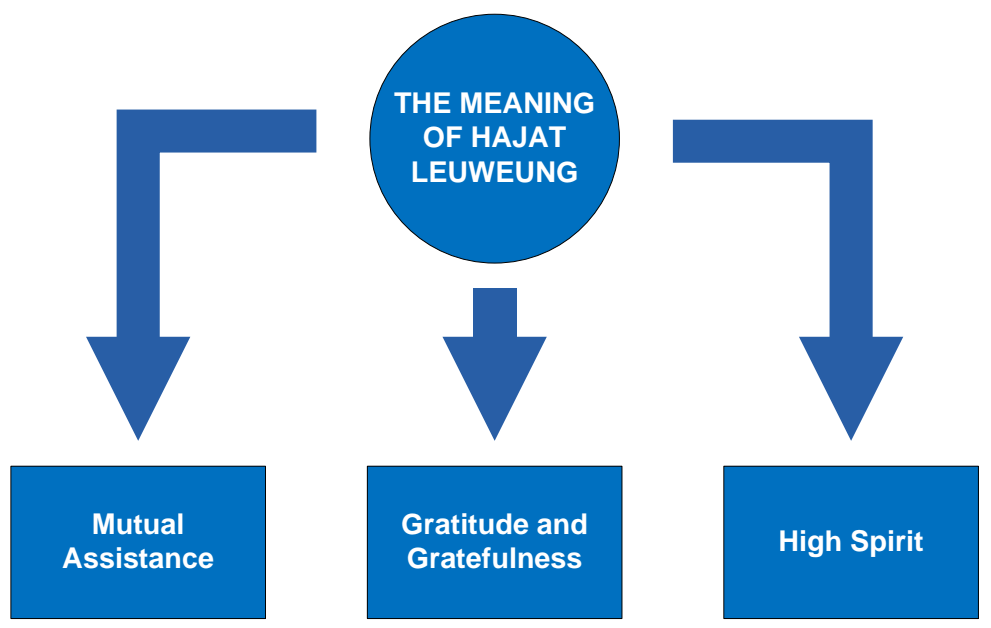

Fig. 2. The Meaning of Hajat Leuweung

Tourism and cultural activists build the meaning of "hajat leuweung" based on experience when they interact. These experiences bring concepts, values, tips, etc. which help them to formulate these meanings. "Hajat leuweung", according to them as an ancestral heritage that means "mutual cooperation, gratitude, and gratitude for the gift given by the creator to humans, and high enthusiasm for building the region".

The meaning of "hajat leuweung" as an act of mutual cooperation which is a legacy of ancestors, because this has become a tradition from the past until now so that it becomes a national culture. In relation to the cultural performance "Hajat Leuweung", the value of mutual cooperation appears in the activities of the local community in making numerous the 
cone (tumpeng) and the torch in the middle of it with three cones larger than the others and decorated in such a way that very interesting to see. All that is done by the community that works together with tourism and cultural activists do not expect anything in return but is carried out for the common interest that is building and promoting tourism based on local wisdom and the environment.

The cultural performance "hajat leuweung" and the arrangement of the tourism objects were carried out based on togetherness between tourism and cultural activists and other community members so that the unity between them was established. The togetherness that exists between them requires sacrifice, both in the form of thought, energy and cost to meet the common needs, and all take place voluntarily without coercion.

Mutual cooperation carried out by tourism and cultural activists are the implementation of cooperation between individuals and groups based on mutual trust to cooperate in carrying out cultural performances "hajat leuweung" and structuring tourism objects that are of mutual interest. For this reason, careful and meaningful collaboration is needed between the various interest groups that pay attention to this activity [2], because collaboration in mutual cooperation is a form of social solidarity.

Another meaning of "hajat leuweung" is gratitude and gratefulness for the gift given by the creator to humans. This gratitude is a sense that arises from tourism and cultural activists who make themselves brave to carry out these activities with high enthusiasm and optimism. Gratitude which was accompanied by the gratitude that appeared to them caused him to always work to build and promote tourism objects without complaints and without forcing help from other parties (the government).

Another thing of gratitude and gratefulness to God can strengthen the relationship between them and strengthen the group's morale in building and promoting tourism in Pangandaran. The social relations that are intertwined between tourism and cultural activists, and with other communities are so familiar and full of family. They routinely gather and communicate both face to face and media to discuss various problems in tourism management.

Cultural and tourism activists often visit local elders to consult about local traditions that are still being carried out, both in the form of traditional rituals and environmental management practices of their lives to be appointed as a tourist attraction based on local wisdom and the environment. This shows that communication with colleagues can build their attitudes and behavior [3]. The gratitude and gratefulness ultimately bring tourism and cultural activists to treat nature as a tourist attraction by caring for and managing it well, not excessive in exploiting and make use of nature and using natural wealth with a purpose as a service.

The last meaning of "hajat leuweung" is the high spirit symbolized by a thousand torches and a large bonfire. Environmental and tourism activists state that in the cultural performance "hajat leuweung", torches and bonfires are an inner drive to take action to open and promote local wisdom-based attractions and the environment.

The emergence of high spirit meaning symbolized by the torch and bonfire, because they feel that the Selasari Village area, Parigi Sub-District, Pangandaran District has a lot of tourism potential to be developed, one of which is the cave and river tourism. For that, they feel that they must act to do something meaningful, both for themselves, others, and their natural environment as an implementation of their feelings of responsibility and care for others. The high enthusiasm for tourism and cultural activists in the cultural performance "hajat leuweung" and the arrangement of tourism objects are their initiatives, not government orders. The emergence of ideas to develop and promote tourism objects through these performances is the result of their creative thinking processes which are then done together. 
The high enthusiasm shown by tourism and cultural activists symbolized by torches and bonfires is the basis for them to show their role as a group of individuals who care about the development of local wisdom and environment-based tourism in Pangandaran District.

The actions taken by tourism and cultural activists in relation to the cultural performance "hajat leuweung" to preserve the surrounding environment, among others, to clean up the environment from organic and non-organic waste carried by visitors, planting pumice plants to maintain water availability, echo the problem of river pollution through the mass media and create the web, facebook, and Instagram on social media, and so on.

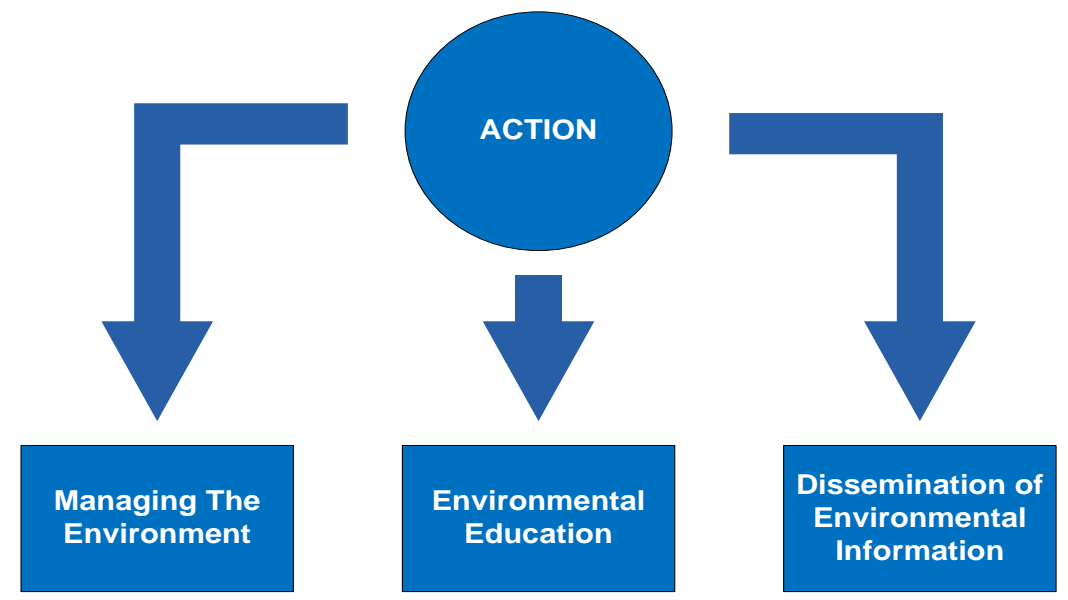

Fig. 3. The Actions Taken by Environmental Activists in Relation to Hajat Leuweung

The actions taken by tourism and cultural activists are based on the subjective meaning of the cultural performance "hajat leuweung" and the arrangement of the tourism objects. These actions are carried out not solely for the sake of self and group, but actions for the mutual benefit of local communities, and the government, even tourists. These shared interests can be accommodated if they have a genuine interest in environmental protection and naturalbased experiences, which are based on respect for the community and local values [5]. Respect for local communities and local values including preserving natural heritage and local culture can be used as a basis for shaping sustainable environmental development [6], so that action is the social act that has meaning. Actions were taken by arranging the tourist environment aim to the magnificence and give comfort to all those who visit the place. The arrangement of the environment in the tourism objects carried out by tourism activists is by building the coherence of its infrastructure, such as the arrangement of parking lots, food / beverage stalls, souvenir shops, parks and farms, walking paths, bathrooms and washing, security facilities, and etc., to open a comfortable view space for tourists visiting the tourist attraction, and also to meet the carrying capacity of tourists in the form of ecological footprints of tourists. Tourism and cultural activists try to be as objective as possible in creating the physical beauty of the cultural scene "hajat leuweung" and its attractions. This means that the value of its beauty comes from habits that have been carried out by its ancestors, both in terms of culture and aspects of the way of managing the environment and the raw materials taken from natural resources in the location.

The purpose of structuring tourism objects carried out by tourism and cultural enthusiasts is to develop a better social life, in the form of better social relations between citizens to build cooperation in developing tourism in these locations. In addition, the arrangement of tourism 
objects is intended to ensure the improvement of the economy of the local community, because they are given the opportunity to conduct economic activities in these locations, such as opening food-beverage stalls, selling souvenirs, being a guide, and so on. Taking into account the beauty, the comfort of spatial planning and the level of welfare will ultimately improve the quality of social relations [9]. Furthermore, the purpose of structuring the tourism object, in the end, is to ensure environmental sustainability.

The cultural performance "hajat leuweung", and the arrangement of the environment of the tourist objects have the value of environmental education that must be known by the public, and students, whose schools are located around tourist attractions. In this activity, the ancestral tradition was introduced (ancestors) including such as building, maintaining, and preserving culture and environment that was full of symbols, such as clothes, cone, torches, and so on. Then in the tourist location introduced methods of waste management, types of plants that can hold water, and so on, the purpose of which is to increase knowledge, and public awareness about a sustainable environment. Other actions taken by tourism and cultural activists in the "hajat leuweung" cultural performance and arrangement of the tourist environment are to disseminate information on tourism development based on local wisdom and the environment. The media used in the dissemination of information are mass media (radio), and social media The media is a communication tool used to transfer information related to environmental management in order to facilitate the implementation of environmental management tasks. The use of radio as a medium for information dissemination is because one of the tourism and cultural activists is a private radio manager. The content presented includes issues related to river pollution from industrial, household, restaurant, etc., which can threaten environmental damage at tourist sites.

Radio is a medium that is quite economical, easy to operate, and carried anywhere so that it can become a "loyal friend" for its owner, this media is actually quite effective to use because it can provide access to information about the environment for the community. The use of radio as a medium for environmental information allows broadcasters and listeners to become more familiar so that they can dialogue about environmental issues that threaten tourism objects in Pangandaran.

Other media that are used by tourism and cultural activists are social media. The use of social media by tourism and cultural activists in the "hajat leuweung" cultural activity and the arrangement of tourism objects is more to share information, and medium to interact. Social media in the form of smartphones by them is used as a learning media for the environment to support the development of tourism in Pangandaran because it is considered easy and quickly accessed. Smartphone as an interactive medium in studying the environment, helping them to obtain information about the efforts of the ancestors to manage the environment, and redistribute the information to their colleagues.

This media are owned by all people involved in cultural events "hajat leuweung" and structuring the tourist environment. In general, smartphone applications are often used by WhatsApp and Facebook. Both of these applications are very helpful for them to receive and deliver information about the environment that is useful for developing tourism based on local wisdom and the environment online. Especially for WhatsApp applications, this media, in addition to exchanging information is also used by tourism activists as a medium for interacting, thinking about current environmental issues. Other applications that are often used by tourism and cultural activists are Facebook. This application is used by them as a discussion forum to develop and promote the local wisdom-based tourism and the environment in Pangandaran. Facebook has a wider scope of public space, so that feedback can come from anyone, and from anywhere, and can form a social network, which of course 
will further increase the horizons of people involved in discussions about tourism and environmental conservation around the tourist attraction.

Certainly when using the media to disseminate information must pay attention to the message that will be received and delivered. The content of the message will be interpreted which can affect the attitude of the communication participant [8].

The cultural performance "hajat leuweung", and the arrangement of the tourism objects carried out by tourism and cultural activists is a form of concern for the program of the Pangandaran District government in the field of tourism. They try to develop and promote new tourism objects, especially in Selasari Village, Parigi Sub-District, in the form of cave and river tours. For that communication involving stakeholders plays a key role in the delivery of information to build an understanding of the development of tourism based on local wisdom and the environment [9]. Of course in this activity, tourism and cultural activists do not forget the aspect of environmental preservation that they get from the process of learning from their ancestors regarding the traditions and learning outcomes through interaction with experts directly and through the media so that he can improve his knowledge in tourism, culture, and environment. The ability of tourism and cultural activists in reading, listening, interpreting, and doing something to the environment means that they have conducted literacy with the environment [11]. This environmental literacy is the foundation for tourism and cultural activists to improve the quality of the environment of the attractions they manage.

\section{Conclusions}

Based on the discussion about the role of tourism and cultural activists in the cultural performance "Hajat leuweung", and the arrangement of the environment the tourism object can be summarized as follows: Tourism and cultural activists hold a cultural performance "Hajat leuweung", and the arrangement of the surrounding environment is driven by their desire to continue the tradition of the ancestors, develop aspects of environmental aesthetics by arranging it according to the concept of order to be beautiful, and apply environmental ethics as a form of moral responsibility towards nature, by preserving and preserving nature. Tourism and cultural activists interpret the cultural performance of "Hajat leuweung", and the arrangement of the surrounding environment as a form of mutual cooperation based on mutual trust to collaborate so that it becomes social solidarity that should be grateful for caring for and managing nature well, and based on high enthusiasm due to their creative thinking process. Tourism and cultural activists in the cultural performance "Hajat leuweung", and the arrangement of the surrounding environment of the tourism object act as an environmental stylist aimed at beauty and provide a sense of comfort for all those who visit the place. Providing environmental education to the community to increase their knowledge and awareness as well as disseminating environmental information using radio and smartphones.

\section{References}

[1] R. Kirkman and N. Voulvoulis, "The role of public communication in decision making for waste management infrastructure," J. Environ. Manage., vol. 203, pp. 640-647, 2017.

[2] T. Osman, D. Shaw, and E. Kenawy, "Examining the extent to which stakeholder collaboration during ecotourism planning processes could be applied within an Egyptian context," Land use policy, vol. 78, no. June, pp. 126-137, 2018. 
[3] M. Potoski and P. J. Callery, "Peer communication improves environmental employee engagement programs: Evidence from a quasi-experimental field study," J. Clean. Prod., vol. 172, pp. 1486$1500,2018$.

[4] I. Niedziolka, "Sustainable Tourism Development," Reg. Form. Dev. Stud., vol. 8, no. 3, pp. 157166, 2012.

[5] A. Carlo, "Sustainable tourism in practice: Promoting or perverting the quest for a sustainable development?," Sustain., vol. 6, no. 5, pp. 2562-2583, 2014.

[6] M. M. Masud, A. M. Aldakhil, A. A. Nassani, and M. N. Azam, "Community-based ecotourism management for sustainable development of marine protected areas in Malaysia," Ocean Coast. Manag., vol. 136, pp. 104-112, 2017.

[7] V. W. Y. Tam, L. Y. Shen, R. M. Y. Yau, and C. M. Tam, "On using a communication-mapping model for environmental management (CMEM) to improve environmental performance in project development processes," Build. Environ., vol. 42, no. 8, pp. 3093-3107, 2007.

[8] N. D. Line, L. Hanks, and L. Zhang, "Sustainability communication: The effect of message construals on consumers' attitudes towards green restaurants," Int. J. Hosp. Manag., vol. 57, pp. 143-151, 2016.

[9] R. Genc, "The Importance of Communication in Sustainability \& Sustainable Strategies," Procedia Manuf., vol. 8, no. October 2016, pp. 511-516, 2017.

[10] M. A. Marfai, Pengantar Etika Lingkungan Dan Kearifan Lokal, Yogyakarta. Gadjah Mada University Press, 2012.

[11] R. R. Jurin, D. Roush, and J. Danter, Environmental Communication. Second Edition. London New York: Springer Science+Business Media, 2010. 